\title{
PRESENCE AS A BASIS FOR THE RECOGNITION AND ENFORCEMENT OF FOREIGN JUDGMENT SOUNDING IN MONEY: THE "REAL AND SUBSTANTIAL CONNECTION" TEST CONSIDERED
}

\section{Introduction}

A somewhat contested basis of international competence in the recognition and enforcement of foreign judgments in South Africa is mere presence. (For the purposes of this note "mere presence" entails mere physical presence. The words like "mere", "transient", "fleeting", "temporary", "short" and "casual" are often used to describe presence. The word preferred in this article is "mere presence".) Over the years, an academic debate has raged in South Africa over mere presence as a basis of jurisdiction for the enforcement of foreign judgments sounding in money. A recent decision by the Constitutional Court makes the topic worth revisiting.

Practical circumstances, social and political considerations as well as natural justice inevitably call for the recognition and enforcement of foreign judgments. (Recognition and enforcement of foreign judgments were thought (by modern states) to be in line with the requirements of comity, which has been stated to be the deference and respect due by other states to the actions of a state legitimately taken within its territory. For a detailed discussion on comity, see Paul "Comity in International Law" 199132 Harvard International LJ 1.) As Forsyth (Private International Law: The Modern Roman-Dutch Law Including the Jurisdiction of High Courts (2012) 417) aptly puts it "[a] plaintiff may sue in one country and hear with pleasure judgment given in his favour, then discover, to his dismay, that the defendant, with his assets, has absconded to another country". In such a situation, the judgment has become brutum fulmen in the court which pronounced it and the plaintiff is placed in a grossly prejudicial position. However, because of widely accepted values and principles, legal systems of the world recognize and appreciate that a judgment rendered by the courts of one country may be enforced elsewhere, provided certain conditions are satisfied.

Under South African common law one of the conditions for the enforcement of foreign judgments is that the court which pronounced the judgment must have had jurisdiction to entertain the case according to the principles of our law with reference to the jurisdiction of foreign courts. (In Reiss Engineering Co Ltd v Insamcor (Pty) Ltd 1983 (1) SA 1033 (W) 1037B the court stated that the mere fact that the foreign court may have had jurisdiction under its own laws, is not conclusive. Instead, the question of jurisdiction has to be determined in the light of the principles of our law on 
the jurisdiction of foreign courts. Other requirements for recognition and enforcement are that (i) the foreign judgment must be final and conclusive in its effect and not have become superannuated; (ii) the recognition and enforcement of the judgment by South African courts should not be contrary to public policy; (iii) the foreign judgment should not have been obtained by fraudulent means; (iv) the judgment must not involve the enforcement of a penal or revenue law of the foreign state; and $(v)$ the enforcement of the foreign judgment must not be precluded by the provisions of the Protection of Business Act 99 of 1978, as amended. See Jones v Krok 1995 (1) SA 667 (AD) 685B-D.) This note is concerned only with the requirement that the foreign court that pronounced the judgment must have had jurisdiction to entertain the case according to the principles of our law with reference to the jurisdiction of foreign courts. The other four requirements are outside the scope of this paper and will not be discussed. It appears that the requirement that the foreign court must have had jurisdiction is a tenet central to the common law world (see Fassberg "Rule and Reason in the Common Law of Foreign Judgments" 199912 Can. JL \& Jurisprudence 193). This requirement is a concept sui generis which is not affected by the internal jurisdiction rules of the foreign court, nor by the internal jurisdiction rules of the South African courts (Malan, Neels, O'Brien and Boshoff "Transnational Litigation in South African Law" 1995282 Journal of South African Law 283; and see also Schulze On Jurisdiction and the Recognition and Enfocement of Foreign Money Judgments (2005) 18). Under South African common law there are, at least, two grounds which have been established with absolute clarity, that clothe a foreign court with international competence.

\section{Common law grounds}

The grounds recognized by South African common law with reference to the jurisdiction of foreign courts for the enforcement of foreign judgments sounding in money were reiterated in Purser $v$ Sales (2001 (3) SA 445 (SCA), where Mpati AJA stated:

"The principles recognized by our law with reference to the jurisdiction of

foreign courts for the enforcement of judgments sounding in money are:

1. at the time of the commencement of the proceedings the defendant ... must have been domiciled or resident within the state in which the foreign court exercised jurisdiction; or

2. the defendant must have submitted to the jurisdiction of the foreign court" (par 12).

This legal position has been confirmed in an overwhelming number of cases. (See Acutt Blain \& Co v Colonial Marine Assurance Co (1882) 1 SC 402; and Benidai Trading Co Ltd v Gouws \& Gouws (Pty) Ltd 1977 (3) SA $1020(\mathrm{~T})$. However, in this case the main issue was whether the parties had submitted to the foreign court's jurisdiction. Boffey $v$ Boffey (1910) 27 SC 195; De Naamloze Vennootschap Alintex v Von Gerlach 1958 (1) SA 13 (T); Du Preez v Phillip-King 1963 (1) SA 801; MacCartie v Bromwich (1897) 4 Off Rep 296 295; Reiss Engineering Co Ltd v Insamcor (Pty) Ltd 1983 (1) SA 103 (W); and Supercat Incorporated v Two Oceans Marine CC 2001 (4) SA 27 (C) 30B. The author could find only two cases, namely: Borough of 
Finsburg Permant Investment Building Society v Vogel (1910) 31 NLR 402 and Erskine v Chanitex Oriental Trading Co 2001 (1) SA 817 (C) 820I-J, where the Court did hold that either physical presence of the defendant within the area of jurisdiction of the foreign court, or his domicile, or his residence within the area of jurisdiction of the foreign court, constituted international competence of the foreign court.) It also appears that all commentators on the subject are in agreement with this legal position (see Schulze On Jurisdiction and the Recognition and Enfocement of Foreign Money Judgments 18).

Approximately five years after Purser was decided, the South African Supreme Court of Appeal (hereinafter "SCA") was called upon to determine on principles recognized by our law with reference to the jurisdiction of foreign courts for the enforcement of foreign judgments sounding in money. In Richman v Ben Tovim (2007 (2) SA 283 (SCA), the central issue, as pointed out by Zulman JA (par 1), was whether the English court that had granted a default judgment against the respondent (the defendant in the court a quo), who was physically present but neither domiciled nor resident in England when the initiating process was served upon him, had had jurisdiction to entertain the matter according to principles recognized by South African law with reference to the jurisdiction of foreign courts. The court first queried why a party armed with a final and conclusive judgment of an English court should not be entitled, prima facie at least, if only on the grounds of comity between civilized nations and having regard to the current global environment, to relief in our courts (par 4). The requirement of international jurisdiction had to be fulfilled according to South African law and also according to the principles of the English law. The court held that the second part of the requirement was a matter of fact, since an English court will have jurisdiction to entertain a claim in personam if the defendant, even if only temporarily present, is served with process in England (par 6).

With regard to South African law the court stated that the seeming suggestion in Purser $v$ Sales that our law would recognize the jurisdiction of the foreign court if at the time of commencement of the proceedings the defendant was domiciled or resident within the State of the foreign court that exercised jurisdiction, or submitted to that court's jurisdiction, but not in cases of temporary presence, was plainly obiter (par 8). After considering the diverse views expressed in South African decisions and scholarly writings, Zulman JA approved the words of Pollak:

"A foreign court has jurisdiction to entertain an action for a judgment sounding in money against a defendant who is a natural person ... [i]f at the time of the commencement of the action the defendant is physically present within the state to which the court belongs ..." (par 8-9; and see Pollak The South African Law of Jurisdiction (1937) 219).

Zulman JA consequently held:

"There are compelling reasons why, as submitted by the plaintiff's counsel, in this modern age, traditional grounds of international competence should be extended, within reason, to cater for itinerant international businessmen. In addition it is now well established that the exigencies of international trade and commerce require 'that final foreign judgments be recognised as far as is reasonably possible in our courts, and that effect be given thereto'” (par 9). 
The English court default judgment was consequently enforced against the defendant. In this case the approval of mere presence as a ground of international competence is unequivocal and forms part of the ratio decidendi of the judgment.

Perhaps predictably, this decision received considerable criticism from some of the most important (scholarly) contributors in this field, submitting that the SCA erred in deviating from the considerable case law in South Africa against presence as a ground and ought to reconsider this issue in the future. (See Forsyth Private International Law: The Modern Roman-Dutch Law Including the Jurisdiction of High Courts 430, where he states that the SCA erred in ignoring the exorbitance of presence as a ground; Schulze "International Jurisdiction in Claims Sounding in Money: Is Richman v BenTovin the last word? 200820 SA Merc LJ 73, where he states that there is no reason why traditional grounds of international competence should be extended to such an extent "that they produce an artificial and intolerable result"; and Oppong "Mere Presence And International Competence In Private International Law" 20073 J Priv. Int'l L. 325-330, where he states that there are aspects of jurisdiction founded on mere presence that suggest that it would be unwise to affirm it as a basis of international competence. He also criticizes the SCA for ignoring the exorbitance of this ground.) However, some commentators were in favour of presence as a ground recognized by our law with reference to the jurisdiction of foreign courts for the enforcement of judgments sounding in money. (See Eiselen "International Jurisdiction in Claims Sounding in Money" 200618 SA Merc LJ 51-52, where he states that there is nothing inherently adverse to expanding the recognition of foreign judgments. He critizes the court heavily a quo in Richman for not recognizing mere presence as a ground recognized by our law with reference to the jurisdiction of foreign courts for the enforcement of judgments sounding in money. See Van Niekerk and WG Schulze The South African Law of International Trade: Selected Topics (2011) 31 fn 18, although they do not express an opinion on the matter seem to have accepted and welcomed the SCA decision.) It should also be remarked that some confusion regarding presence as ground of international competence recognized in South African law arose when, in the second edition of Pollak (On Jurisdiction (1993) 162-164), Pistorius, the editor of that edition, omitted the first ground (presence), ostensibly on the basis that there had been no authority for its inclusion in the original edition. He suggested (164) that the "weight of authority of other writers" was against it (in this regard, he referred to Forsyth Private International Law 2ed (1990) 343 fn 69; and Leon "Roma non locuta est: The Recognition and Enforcement of Foreign Judgments in South Africa" 198316 CILSA 337-338).

Approximately five years after Richman was decided, the Constitutional Court (albeit, in a somewhat different context) had the opportunity to reiterate on the principles recognized by our law with reference to the jurisdiction of foreign courts for the enforcement of foreign judgments sounding in money. In Government of The Republic of Zimbabwe $v$ Fick (2013 (CCT 101/12) ZACC 22; and this case dealt with recognition and enforcement of an order by the SADEC tribunal against the Government of the Republic of Zimbabwe. This tribunal exercises jurisdiction of states by 
virtue of their being SADC Member States), after making reference to Purser, Mogoeng CJ held:

"That a foreign court had jurisdiction in terms of the laws of its country does
not, without more, clothe our courts with the jurisdiction to enforce a judgment
of that foreign court. And of the common law jurisdictional requirements to be
met in this case to enable our courts to entertain applications for the
recognition and enforcement of foreign orders, the most relevant are: (i) a
party who applies for the enforcement of a judgment sounding in money 'must
have been domiciled or resident within the State in which the foreign
exercised jurisdiction' or (ii) the one against whom the order is sought to be
enforced must have submitted to the jurisdiction of the foreign court" (par 21).

In the entire judgment there is no mention of mere presence as a common law ground recognized by our law with reference to international competence. In this case the enforcement of the foreign order was not on the basis of mere presence and so it was not necessary for the court to deal with this ground. However, given the uncertainty regarding the existence of this ground in our law, it was hoped that the court would express an opinion in this regard. Mogoeng $\mathrm{CJ}$, however, did make a scant reference to Richman. In this regard the Chief Justice took cognizance of and welcomed the two reasons advanced in Richman in favour of developing the common law jurisdictional principles recognized by our law (par 55; and the two reasons advanced in Richman are "that (i) enforcement is what is required by the exigencies of international trade and (ii) because not to do so might allow certain persons habitually to avoid the jurisdictional nets of the courts and thereby escape legal accountability for their wrongful actions"). The Chief Justice, however, was not inclined to express any opinion on mere presence as a jurisdictional ground recognized by our law with reference to recognition and enforcement of foreign judgments. This makes it difficult to ascertain whether the court supported or, at most, accepted mere presence as a ground recognized by our common law with reference to the jurisdiction of foreign courts for the enforcement of foreign judgments sounding in money. As a result it can be argued that the position regarding presence as a ground in our law is somewhat uncertain. More confusing is the fact that in the above quoted paragraph Mogoeng $\mathrm{CJ}$ uses the words "the most relevant (grounds)". Perhaps there would have been more clarity had the Chief Justice stated "the relevant (grounds)" or "the only relevant (grounds)".

\section{$3 \quad$ Nature of presence as a ground}

Critics of mere presence in leading texts base their criticism on the nature of this ground. They submit that this ground is excessive or exorbitant and therefore leads to an arbitrary exercising of jurisdiction (see Forsyth Private International Law: The Modern Roman-Dutch Law Including the Jurisdiction of High Courts 430; Oppong $20073 \mathrm{~J}$ Priv. Int'l L. 327-329; and Schulze 200820 SA Merc LJ 72-73). This criticism is not baseless. The somewhat cruel nature of mere presence as a ground is evident in cases where jurisdiction was assumed (by a foreign court) on this ground. For instance, in Herman v Meallin ((1891) 8 WN (NSW) 38), a New South Wales court enforced a Victorian default judgment given against the defendant. The Victorian Court had assumed jurisdiction while the defendant was "passing through" Victoria to New South Wales. In Carrick v Hancock (1995 12 TLT 
59), an English court enforced a Swedish judgment given against the defendant. The Swedish court had assumed jurisdiction while the defendant was on a "short visit" to Sweden. In Forbes v Simons ((1914) 20 DLR 100), an Alberta Supreme Court enforced a British Columbia judgment against the defendant. The British Columbia Court had assumed jurisdiction while the defendant was on "a casual visit" to his ill wife in Vancouver. The cruel nature of mere presence as a ground of international competence is immediately evident on the facts and circumstances of these cases.

Forsyth submits that in a world of widespread international travel mere presence is an almost arbitrary ground of jurisdiction (Forsyth Private International Law: The Modern Roman-Dutch Law Including the Jurisdiction of High Courts 430). He argues that this ground does not ensure any connection between the defendant and the court or the dispute and the court and thus does not guarantee effectiveness, unless accompanied by arrest, which is, of course, an act that is now constitutionally proscribed (Forsyth Private International Law: The Modern Roman-Dutch Law Including the Jurisdiction of High Courts 430). The unconstitutionality of arrest to found or confirm jurisdiction was declared in Bid Industrial Holdings $v$ Strang ([2007] SCA 11 (RSA) 59).

Schulze submits that, when Pollak claims that the doctrine of effectiveness is also the proper basis of the jurisdiction of the foreign court, he contradicts his own argument that a foreign court has jurisdiction to entertain an action for a judgment sounding in money if, at the time of the commencement of the action, the defendant is merely physically present within the State to which the court belongs and owns no assets within the area of jurisdiction of the court (Schulze 200820 SA Merc LJ 70). This argument cannot be faulted because the underlying idea of the doctrine of effectiveness is to ensure the effectiveness and enforceability of the foreign court within its own jurisdiction. Indeed, so highly regarded is this requirement of effectiveness in South African law that it has been argued and held that, as between two peregrines, submission alone is not sufficient to confer jurisdiction on the South African courts (Chong Sun Wood Products Pty Ltd v K \& T trading Ltd 2001 (2) SA 651; and Hulse-Reutter v Godde 2001 (4) SA 1336). If the mere presence of the defendant within the area of jurisdiction of the court is then considered to suffice to grant jurisdiction to a foreign court, then the effectiveness and enforceability of the judgment would have to be ignored. From this point of view it is difficult to reconcile mere presence as a basis of international competence with the doctrine of effectiveness, which has been so persistent in our law.

Oppong submits that jurisdiction founded on mere presence arguably undermines the legitimate expectations of defendants. In this regard he states:

"A defendant may legitimately expect to be sued in the State where he is domiciled, resident, does business, voluntarily submits to the exercise of jurisdiction or where the cause of action arose. A defendant hardly expects to be served with a claim form to which he must defend or at least contest on the pain of a default judgment given against him while shopping duty-free in transit at Heathrow. The prospect of another country enforcing such a judgment is even more frightening. Furthermore, such jurisdiction is open to abuse" (Oppong 20073 J Priv. Int'l L. 327). 
Internationally, mere presence has long been widely considered to be an excessive or exorbitant ground of jurisdiction (see De Winter "Excessive Jurisdiction in Private International Law" 196817 International \& Comparative Law Quarterly 712-713; and see also Oppong $20073 \mathrm{~J}$ Priv. Int'l L. 327-328), so much so that, as regards European Union domiciled defendants, this basis of jurisdiction is proscribed under Article 3(2) of the Brussels Regulation (Council Regulation (EC) NO 44/2001 [2001] OJ L21/1). It is noteworthy that as much liberal as the Regulation has been said to be, a foreign judgment against a European Union-domiciled defendant founded on mere presence shall not be recognized under the Regulation.

It is not surprising that a considerable criticism of mere presence as a basis of international competence has stemmed from a human-rights perspective, and more particularly in the context of the cardinal right to a fair trial. It is said that jurisdiction founded on mere presence arguably offends the fundamental principles of fairness and reasonableness on which legal systems are founded (Oppong $20073 \mathrm{~J}$ Priv. Int'l L. 327-328). There is a distinct advantage, so the argument goes, to plaintiffs suing in a forum of their choice, even if that is where a defendant was merely present (Oppong $20073 \mathrm{~J}$ Priv. Int'l L. 327-328). In this instance, considerations of costs, legal aid, limitations, extent of possible awards and the applicable law are said to be some of the factors that plaintiffs may be influenced by in making this choice and thereby fulfil their self-interests. Further, since a court clothed with jurisdiction founded on mere presence may have no substantial connection to the case at all, the argument that a defendant's legitimate interests in such a situation may be compromised is not without basis. (Issues such as high costs may make it impossible for a defendant to attend court proceedings abroad where jurisdiction was assumed on the basis of his mere/temporal presence while in transit attending to an emergency elsewhere. For instance, in Richman it seems that the plaintiff may have pulled a trick over the defendant as it appears from some of the defendant's defences that he had been misled by the nature of the documents served on him whilst in England, and that he had relied on an undertaking by the plaintiff not to institute proceedings against him in England, see Richman $v$ Ben-Tovim 2005 JDR 1044 (C) par 6.)

The argument, on the other hand, in support of international competence founded on presence is that it is in the interest of international commerce that rights created by a foreign judgment should be recognized and enforced like any other right acquired under foreign law (2006 18 SA Merc LJ 52). Further, so the argument goes, denying mere presence as a ground for international competence with reference to enforcing foreign judgments might allow certain persons habitually to avoid the jurisdictional nets of the courts and thereby escape legal accountability for their wrongful actions (Richman v Ben Tovim supra par 9).

It is apparent that academics are divided over presence as a ground of international competence. On the one hand, those who are critics of this ground submit that such a ground is arbitrary and therefore undesirable. On the other hand, those who are proponents of it submit that such a ground in the modern world is commercially sound as it ensures that "itinerant international businessmen" do not escape the jurisdictional nets of courts. 
Be that as it may, it is apparent that the question whether or not a foreign judgment given on the basis of mere presence ought to be recognized and enforced involves, at least, two competing interests, namely: the rights of a defendant to a fair trial on the one hand and the facilitation of international trade (and by extension the rights of the plaintiff who seeks to enforce such a foreign judgment) on the other. This inevitably requires a balancing of these interests in a given case. The courts in other jurisdictions have attempted to craft a (jurisdictional) mechanism that seeks to balance these competing interests. One such mechanism is the so-called "real and substantial connection" test. This test is considered below.

\section{The "real and substantial connection" test}

The "real and substantial connection" test was first introduced in 1990 by the Supreme Court of Canada (hereinafter "SCC") in the context of presence as a ground of international competence with reference to foreign judgments. In Morguard Investments Ltd v De Savoye ([1990] 3 S.C.R. 1077 (Can.)), the plaintiff obtained default judgment in Alberta and sought to enforce this in British Columbia. Under the traditional rules relating to enforcement of "foreign" judgments, the British Columbia court would not have recognized the jurisdiction of the Alberta court and would not have enforced the judgment because the defendant was not a subject of Alberta when the judgment was obtained, was not a resident of Alberta when the action began, and had not submitted to the jurisdiction of the Alberta courts. In evolutionary foundings, the Supreme Court of British Columbia and the British Columbia Court of Appeal allowed enforcement of the judgment in British Columbia. (In Canada, the enforcement of a judgment by one province in another is considered to be the enforcement of a foreign judgment, although as a practical matter, Canadian courts will scrutinize the judgments of those issued in another Canadian jurisdiction with less rigor than they will scrutinize judgments coming from another country, see Koehnen and Klein "The Recognition and Enforcement of Foreign Judgments in Canada" 2010 4. This is a paper delivered at the International Bar Association Annual Conference in Vancouver htt://www.mcmillan.ca/file/ 132622_paper_\%recognition\%20enforcement\%20foreign\%jedgments\%20C anada\%20IBA\%Vancouver\%200ctober\%2010\%(co-\%20(2).pdf (accessed 2013-09-05)).

The matter came before the SCC. The SCC, showing deference to the constitutional principles of "order" and "fairness", introduced a new principle to determine when a court has exercised jurisdiction appropriately for the purposes of enforcement by the court of another province. Differently put, under what circumstances is a judgment rendered on the basis of mere presence by a court in one province enforceable in another? An attempt to answer this fundamental question led to the establishment of the "real and substantial connection" test. The "real and substantial connection" test entails that the court in proceedings seeking to enforce a foreign judgment rendered on the basis of mere presence has to first enquire whether there is a real and substantial connection between the court of another province (that rendered the judgment) and the conduct giving rise to the action. If indeed there is a real and substantial connection then the foreign judgment is 
enforceable. If such a connection is lacking then the foreign judgment should not be enforced. While the decision in Morguard was rendered in the context of inter-provincial enforceability of judgments and did not specifically address the issue of enforcement of foreign judgments, the SCC emphasized that the "real and substantial connection" test also applies to judgments from outside Canada (Richman v Ben Tovim supra par 19).

The SCC did not, however, seek to determine the precise content of the "real and substantial connection" test nor did it elaborate on the strength of the required connection. Rather, the court held that the connection between the matter and the parties, on the one hand, and the court, on the other, must be of some significance in order to promote "order" and "fairness" (par20). In casu, the court allowed enforcement in British Columbia of the judgment rendered by an Alberta court that assumed jurisdiction on the ground of mere presence on the basis that the cause of action arose in Alberta and that the applicant party that sought to enforce the judgment was domiciled and resident in Alberta. This entailed that the requisite substantial connection was present. The court stated that the test is susceptible to supplementation and further developments in the future in order to be consistent with circumstantial change (par 24). It is important to note that the "real and substantial connection" test is used in the context of mere presence as a ground of international competence by Canadian common law courts in enforcing a foreign judgment rendered on jurisdiction founded on this ground but is also used in assumption of jurisdiction by Canadian common law courts where a foreign plaintiff seeks to bring an action/application against a Canadian defendant in common law Canada.

Most recently, and twenty two years after Morguard was decided, the SCC in Club Resorts Ltd v Van Breda ([2012] 1 S.C.R. 525; and for a discussion of the facts of this case, see Monestier "(Still) A 'Real and Substantial' Mess: The Law Of Jurisdiction In Canada" 201336 Fordham International LJ 404-413) reiterated on, and supplemented, the "real and substantial connection" test. Justice LeBel, writing for the unanimous court, first discussed the interplay between the constitutional dimension of the "real and substantial connection" test and the private international law dimension of the test. Precisely, he clarified that the "real and substantial connection" test which imposed territorial limits on adjudicative jurisdiction was distinct from the "real and substantial connection" test as expressed in conflicts rules. (Par 23. In this regard Justice LeBel elaborated: "[f]rom a constitutional standpoint, the Court has, by developing tests such as the real and substantial connection test, sought to limit the reach of provincial conflict rules or the assumption of jurisdiction by a province's courts. However, this test does not dictate the content of conflicts rules, which may vary from province to province. Nor does it transform the whole field of private international law into an area of constitutional law. In its constitutional sense, it places limits on the reach of the jurisdiction of the province's courts and on the application of provincial laws to interprovincial or international situations. It also requires that all Canadian courts recognize and enforce decisions rendered by courts of the other Canadian provinces on the basis of a proper assumption of jurisdiction. But it does no establish the actual content of rules and principles of private international law, nor does it require that those rules and principles be uniform".) 
The Justice then proceeded to the heart of the argument: how to define the "real and substantial connection" test, for conflict-of-laws purposes, in the tort context. Justice LeBel highlighted the tension existing between "a search for flexibility, which is closely connected with concerns about fairness to individuals engaged in litigation, and a desire to ensure greater predictability and consistency in the institutional process for resolution of conflict-of-laws issues related to the assumption and exercises of jurisdiction" (par 66). Ultimately, he bravely concluded that, to the extent that there is a conflict between "justice and fairness", on the one hand, and "certainty and predictability", on the other, the former must yield to the latter (par 73).

The court then proceeded to craft and establish a new framework for the assumption of personal jurisdiction in tort cases in common law Canada. First, a plaintiff must fit himself within one of four presumptive connecting factors:

(a) The defendant is domiciled or resident in the province;

(b) the defendant carries on business in the province;

(c) the tort was committed in the province (par 90);

(d) a contract giving rise to or connected with the dispute was concluded in the province.

The court, however, was quick to note that this list of presumptive factors is not closed. The court held that "[o]ver time, courts may identify new factors which also presumptively entitle a court to assume jurisdiction" (par 90). The court stated that, in formulating new connecting factors, courts should look for connections that give rise to relationships that are similar to the four presumptive connecting factors. Relevant considerations include (par 91):

(a) Similarity of the connecting factor with the recognized presumptive connecting factors;

(b) treatment of the connecting factor in the case law;

(c) treatment of the connecting factor in statute law; and

(d) treatment of the connecting factor in the private international law of the other legal systems with a shared commitment to order, fairness and comity.

The court stressed that, where no presumptive factor (whether listed or new) applies, a court should not assume jurisdiction. Specifically, a court should not assume jurisdiction on the basis of the combined effect of a number of non-presumptive connecting factors (par 92). This would open the door to case-by-case determinations of jurisdiction, which would undermine the order and predictability that the new test is designed to foster (par 93). Once a plaintiff has established that a presumptive factor applies, the onus shifts to the defendant to rebut the presumption of a "real and substantial connection". If a defendant is able to rebut the presumption, then jurisdiction simpliciter has not been established and a court should not hear the case. (Jurisdiction simpliciter entails a forum's ability to assume jurisdiction and connotes personal jurisdiction. This expression, which first appeared in this context in Canadian International Marketing Distributing v Nitsuko (1990) 68 
DLR 318, denotes the existence of jurisdiction as a matter of law and is distinguished from the discretionary exercise of jurisdiction. The phrase has the imprimatur of the Supreme Court of Canada, see Unifund Assurance Co. of Canada v Insurance Corp. of British Columbia (2003) 2 SCR 63 par 33; and Spar Aerospace Ltd v American Mobile Satellite (2002) 4 SCR 205 par 21.) Where a "real and substantial connection" has been established, a court may then consider a defendant's application to stay proceedings on the basis of forum non convenience. The court stated that a clear distinction, however, must be drawn between jurisdiction simpliciter and forum non convenience; the latter comes into play only after jurisdiction is established (par 109). The court emphasized that the forum non convenience doctrine requires the defendant to establish that the alternative forum proposed "is clearly" more appropriate than the domestic forum. Where the other forum proposed is only marginally more appropriate, a motion for stay of proceedings should be denied. In this regard, Justice LeBel stated that, "[i]t is not a matter of flipping a coin" (par 109). Relevant factors in the forum non convenience inquiry include the location of parties and witnesses, the cost of transferring the case to another jurisdiction or of declining the stay, the impact of a transfer on the conduct of the litigation or on related or parallel proceedings, the possibility of conflicting judgments, problems related to the recognition and enforcement of judgments, and the relative strengths of the connections of the two parties (par 110).

After laying out the new framework for the assumption of jurisdiction, the court accordingly proceeded to apply the law to the facts of the case. The court concluded that the case could be resolved on the basis that the contract related to the tort action was entered in Ontario. The court stated that " $[\mathrm{t}]$ he events that gave rise to the claim flowed from the relationship created by the contract" (par 117). It further noted that Club Resorts had not rebutted the presumption of jurisdiction that arises from the application of this presumptive factor, nor had it shown that there was another forum that was "clearly" more appropriate than Ontario for the resolution of the action.

Although the SCC in Club Resorts addressed the "real and substantial connection" test in the context of Canadian courts assuming jurisdiction in torts that occurred outside Canada, the case is important also in the context of enforcement of foreign judgments in that Canadian courts will recognize and enforce a foreign judgment only if the foreign court that rendered the judgment had assumed jurisdiction on the grounds, principles and values recognized by Canadian courts (except in the province of Quebec (as a civil law jurisdiction)). Since mere presence on its own is not sufficient to clothe common law Canadian courts with jurisdiction, by the opposite side of the same coin a foreign judgment rendered by a court that exercised jurisdiction solely on the basis of mere presence won't be enforceable in common-law Canada. Simply put, mere presence as a ground of international competence must further be accompanied or supplemented by, at least, one "connecting factor" to the foreign court in order for such judgment to be enforceable in common law Canada. In other words, the "real and substantial connection" test must be satisfied to render the foreign judgment enforceable. 


\section{$5 \quad$ Richman revisited}

Forsyth states that the development of the rules of private international law, whether by the legislature or by the judges, should take place only after a careful comparative study of the relevant rules applied elsewhere in the world. Indeed in Richman, because of the nature and significance of the central (international) issues and interests, the SCA ought to have considered a comparative study of developments and analysis from other jurisdictions with a shared commitment to order, fairness and comity (of all the cases that the court made reference to, none of them originated from foreign jurisdictions). There are crucial pertinent aspects that the court should have sufficiently considered before deviating from the considerable case law in South Africa against mere presence as a ground and accepting that traditional grounds of international competence should be extended "to cater for itinerant international businessmen". The SCA's silence on inherent dangers of international jurisdiction founded on mere presence indicates that the court did not sufficiently give due regard to balancing the competing interests as required by a case of such nature. Further, the fact that the court did not note the excessiveness or exorbitance of mere presence as a ground is unsettling. Had the SCA investigated and unraveled the multi-dimensional nature of the crucial pertinent aspects involved, the court might have appreciated the complexity of these aspects. This might have guarded it to proceed with caution and perhaps appreciate the fact that such a case warranted a comparative analysis of the relevant rules in other progressive jurisdictions.

Another unsettling issue is the fact that in "extending" the common law grounds for international competence the SCA did not highlight the constitutional aspects relevant when a court takes measures to develop the common law. Of pivotal importance is section 39(2) of the Constitution (the Constitution of the Republic of South Africa, 1996). This section requires a court, when developing the common law, to promote the spirit, purport and objects of the Bill of Rights. There is no reason why the SCA did not consider the provisions of the Constitution. This also might have led the court to acknowledge that the excessiveness or exorbitance of mere presence as ground renders it artificial and arbitrary rather than fair and reasonable. This makes this ground to be somewhat incompatible with some of the cardinal values and principles that underlie our constitution. This is probably one of the reasons the Constitutional Court in Government Of The Republic Of Zimbabwe $v$ Fick was not vocal on this ground and did not confirm it as one of the bases for enforcement of foreign judgments in our common law. There have been warnings against prioritizing the international system on the strength of arguments like the need to facilitate international trade and commerce since this may mean that interests and values of individual parties to the litigation are lost or dealt with unfairly (see Wai "In the Name of the International: The Supreme Court of Canada and the Internationalist Transformation of Canadian Private International Law" 2009 39 Canadian Yearbook of International Law 117, 186-188). The nature of the Richman case warranted a comparative study of the relevant rules from other progressive jurisdictions. In particular, in an attempt to mitigate the arbitrariness of mere presence as a ground, I submit that the SCA should 
have at least considered the "real and substantial connection" test as an additional basis to mere presence as a ground in Richman.

\section{Application of the "real and substantial connection" test in Richman}

In Richman the following connection or link to the relevant English court was present:

(a) locus contractus;

(b) locus solutionis;

(c) the appellant (party seeking to enforce the judgment) was resident (and possible domiciled in England; and

(d) performance or payment was to be effected in English currency.

Mere presence is said to be an exorbitant and arbitrary ground of jurisdiction in that it does not ensure connection between the dispute and the court (unless accompanied by arrest of which has been declared unconstitutional). Therefore, in affirming mere presence as a ground sufficing international competence in reference to foreign judgments, the SCA should have noted the connection to the English court that rendered the default judgment and use such connection as an additional basis of international competence qualifying mere presence as a ground in this case. This would have assisted in militating the exorbitance of this ground. Had this been the case, the position would, thus, be that: mere presence on its own is insufficient to suffice international jurisdiction in that it is excessive and exorbitant and therefore arbitrary. Thus, for it to suffice international competence it ought to be accompanied and, thus, qualified by a substantial link or connection to the court that assumed jurisdiction on the basis of mere presence. There is a case to vest international jurisdiction in a court linked to the dispute through a ratio jurisdictionis. Most jurisdictions in Europe also follow this pattern in determining a forum that is/was most suitable to hear a matter. Had the SCA used the connection/link to supplement mere presence, its decision to extend our traditional grounds of international competence (to ensure that "itinerant international businessmen" do not escape the "jurisdictional nets of courts" and to facilitate international trade and commerce) would have been arguably justified. It is surprising to note that this connection was not mentioned or advanced in any of the proceedings by the parties.

\section{$7 \quad$ Conclusion and submissions}

Practical considerations and "enlightened social values" dictate that final foreign judgments should be recognized as far as is reasonably by our courts. The principle of comity requires that a state should generally defer to the interests of foreign states with due regard to the interests of its own citizens and the interests of foreigners under its jurisdiction in order to foster international cooperation. The import of the principle of reciprocity (this doctrine means that a judgment of a court of country $X$ will be recognized and enforced only in country $Y$ if the courts of country $X$ also recognize and 
enforce judgments of courts of country $\mathrm{Y}$ in similar circumstances) is that courts of a particular state should enforce final judgments of foreign courts in the expectation that foreign courts would reciprocate. This also strengthens the cordial relations that have been established amongst civilized and progressive nations. This, further, promotes the orderly conduct of international trade, which is central to the enforcement of judgments rendered by foreign courts.

It appears to me that the above mentioned principles were also developed and established to ensure that lawful judgments are not to be evaded with impunity by any person in the global world, and to give effect to rights legitimately created by a foreign judgment. When evaluated against this background, it appears that the result in Richman is justifiable. However, what seems unjustifiable is how the court arrived at the result.

I propose that when hearing a matter regarding enforcement of a foreign judgment in the context of mere presence, the SCA should engage in a comparative study of the relevant rules in other progressive jurisdictions that have a shared commitment to international trade, order, fairness and comity. In particular, the SCA should consider the Canadian "real and substantial connection" test that supplements mere presence as a basis of international competence (the Falconbridge case example). Of course, the test has not been immune to criticism. Mortensen has argued that the "real and substantial connection" test probably gives Canada the most generous and liberal rules for the recognition and enforcement of foreign judgment in the world. (See Mortensen Private International Law in Australia (2006) 136. For an extensive comment on the "real and substantial connection" test, see generally Castel "The Uncertainty Factor in Canadian Private International" 200752 Canadian LJ 555; and Monestier 201336 Fordham International LJ 396.) Forsyth, one of the authoritative commentators in South Africa on conflict of laws, has argued that such a test "devoid of precise meaning, simply provides a veil of judicial discretion, and is therefore not supported as a ground for international competence" (Forsyth Private International Law: The Modern Roman-Dutch Law Including the Jurisdiction of High Courts 401-402). I respectfully submit that indeed this test is not a perfect solution for the enforcement of foreign judgments and jurisdictional woes caused by somewhat jaded traditional common law grounds, some which struggle to keep up with value-based attitudes of present time. However, what cannot be taken away from this test is its legitimate attempt to balance the competing interest of the individual parties in cases where enforcement of a foreign judgment rendered on the basis of mere presence is sought. Although EU law is often perceived as a model to follow in this regard, it is important to note that the measures taken by the EU with reference to exorbitant or excessive jurisdiction do not address the crucial issue in this regard. For instance, the most unappealing feature of the Brussels Regulation (Council Regulation (EC) NO 44/2001 [2001] OJ L21/1) from the perspective of non-Member States is the fact that a judgment rendered in a Member State (on exorbitant bases of jurisdiction) against a defendant not domiciled in any Member State (non-EU-domiciled defendant) is entitled to recognition and enforcement in another Member State under the Regulation's liberal regime which does not permit the review of the jurisdiction of the rendering court (see Art 35(3)), even if the latter assumed 
jurisdiction is considered on an exorbitant basis as listed in Annex I (Art $3(2)$ ). The Regulation in this regard proscribes exorbitant basis of jurisdiction only as against parties domiciled in EU Member States. On the other hand, the Canadian "real and substantial connection" test, which is founded on constitutional basis and is of general application, allows constitutional values and principles such as "fairness" and "order" to permeate through and pierce the veil of established traditional jurisdictional and enforcement grounds that seem out of line with the value-based attitudes of modern times. I submit that the "real and substantial connection" test (as faulty as it is, as has been pointed out by some critics who have not suggested a better solution or technique) is clearly worth exploring by our courts when in need of comparative guidance in cases of a nature such as the Richman case. A stone from other hills may serve to polish the jade of this one. There is nothing inherently adverse in resorting to a pragmatic and effective foreign technique when circumstances deem it necessary and sensible to do so. Our courts have effectively imported from foreign jurisdictions when circumstances called for this. In adopting the via media (the via media doctrine was formulated by the Canadian by the Canadian conflicts lawyer Professor John Delatre Falconbridge (1875-1968), writing on the subject of classification during the 1930s and the 1950s) classification with reference to liberative prescription, Schutz J, in the Laurens case held:

"For myself, I accept the via media and propose to follow it through wherever it leads. We may not dare to let our law stand still ... [P]rivate international law is a developing institution internationally, and ... our own South African private international law cannot be allowed to languish in a straitjacket" (Laurens $v$ von Hohne 1993 (2) SA 104 (W) 116H-117E).

2500 years ago, the Chinese philosopher Confucius (Confucius, one of the most famous philosophers in ancient China, lived between 551-479BC; he sometimes went by the name of Kong $\mathrm{Zi}$; and see also Qishen He "The EU Conflict Communitarization and the Modernization of Chinese PIL" 2012 Rabel Journal of Comparative and International Law 48) said, "[w]hen I walk along with two others, they may serve me as my teachers. I will select their good qualities and follow them, identify their bad qualities and avoid them". It is so for judges as well as practitioners generally around the world, and there is no doubt that they should do so for the building of legal systems.

GMN Xaba

Legal Intern ProBono.Org, Johannesburg 